\title{
Factors Explaining Business Student Attitudes Towards Mathematics: Does Gender Still Matter?
}

\author{
Leiv Opstad ${ }^{1 *}$ \\ ${ }^{1}$ Norwegian University of Science and Technology, NORWAY \\ * Corresponding author: leiv.opstad@ntnu.no
}

Received: 6 Jan. $2021 \bullet$ Accepted: 27 Feb. 2021

Citation: Opstad, L. (2021). Factors Explaining Business Student Attitudes Towards Mathematics: Does Gender Still Matter?. European Journal of Science and Mathematics Education, 9(2), 13-25. https://doi.org/10.30935/scimath/10771

\begin{abstract}
:
The purpose of this paper is to identify factors that can explain the attitudes of business students towards mathematics, using data from a business school in Norway. This article focusses on gender, personality traits (Big Five Model) and mathematical background. The independent variables were investigated simultaneously using a linear regression model. Mathematical abilities are important for success in business studies, and therefore, attitudes towards mathematics matter, since they will affect students' effort and their choice of further studies. It was found that mathematical background has the strongest effect on student attitudes towards mathematics. Personal characteristics also explain the variation in the attitudes towards mathematics to some degree. Gender has little or no impact on the dependent variable. If there is any gender difference it is in favour of female students.

Keywords: gender differences, attitudes towards mathematics, Big Five, mathematical skills, independent t-test, regression analysis, business school
\end{abstract}

\section{INTRODUCTION}

Many factors influence students' attitudes towards mathematics including the teacher's view of the use of mathematics (Marbán \& Mulenga, 2019; Schaeffer et al., 2020). Our investigation of this topic will include mathematical skills and personality traits using the Big Five Model.

\section{Career}

Attitudes towards, and belief in mathematics, influence a student's decisions about study and career path (Recber et al., 2018). Students who enjoy mathematics and have good mathematical skills tend to choose quantitative fields of study (Alcock et al., 2008; Larson et al., 2010). The choice depends on the student's emotions and feelings about mathematics, Mathematical topics are important in many fields, including business studies (Opstad, 2018). It is important to investigate business student attitudes towards mathematics, since this might have an effect on student choices of further studies. Furthermore, there is a link between performance in mathematics and attitudes towards mathematics (Hemmings \& Kay, 2010).

\section{Gender Effect}

The subject of the gender differences in mathematics and attitudes towards mathematics continues to attract interest among researchers worldwide (Stoet \& Geary, 2018). Gender differences in mathematics might explain the underrepresentation of women in science, technology, engineering and mathematics (STEM). According to Stoet and Geary (2018), even in countries with a high level of gender equality, 
Table 1. Attitudes toward Mathematics Inventory (ATMI)

\begin{tabular}{|c|c|}
\hline Trait & Description \\
\hline \multirow[t]{3}{*}{ Self-Confidence (S) } & Students have high confidence and self-concept in their performance in mathematics. \\
\hline & They believe in success in mathematics. \\
\hline & Example item: Mathematics does not scare me at all. \\
\hline \multirow[t]{2}{*}{ Value of Mathematics $(\mathrm{V})$} & $\begin{array}{l}\text { Students see the usefulness, relevance and worth of mathematics in their life, now and in the } \\
\text { future. }\end{array}$ \\
\hline & Example item: Mathematics is important in everyday life. \\
\hline \multirow[t]{2}{*}{ Motivation (M) } & Students are interested in mathematics and wish to pursue studies in mathematics. \\
\hline & Example item: The challenge of mathematics appeals to me. \\
\hline \multirow[t]{2}{*}{ Enjoyment of Mathematics (E) } & Students joy working with mathematics. \\
\hline & Example item: I like to solve new problems in mathematics. \\
\hline
\end{tabular}

such as Norway, women are still underrepresented in STEM. Business studies is not male-dominated field in Norway, and there are approximately the same number of females as males in the field. Despite this, there is a gender difference in the degree choices of undergraduate students. Females prefer nonquantitative courses (marketing, management etc.), while quantitative fields like finance attract males (Opstad, 2019). This is in in line with the findings of Worthington and Higgs (2004).

\section{The Purpose}

The purpose of this research was to find out more about this issue. Is there a gender difference in attitudes towards mathematics among undergraduates in business studies in Norway? What impact does a mathematical background in secondary school have on attitudes towards mathematics? Studying mathematics is compulsory for the two first years of upper secondary school. Second year students can choose mathematics for natural science (N-maths), which includes the calculation and analysis of figures, geometry, and use of vectors. It is also possible to specialise in the same area in the third year.

\section{RESEARCH INSTRUMENT}

\section{Attitudes Towards Mathematics Inventory (ATMI)}

The instrument for measuring student attitudes towards mathematics was developed over a long period. Attitudes play an important role in learning mathematics, and for a student's choice of study fields (Ngurah \& Lynch, 2013). Many models are available (Unfried et al., 2015). According to Pepin (2011), the Fennema-Sherman Mathematic Attitudes Scales (MATS) is popular among the researchers. This instrument was developed by Fennema and Sherman (1976) and includes nine factors: (1) Attitude towards Success in Mathematics, (2) Male Domain, (3) Mother Scale, (4) Father Scale, (5) Teacher Scale, (6) Confidence, (7) Anxiety, (8) Motivation and (9) Usefulness. Another approach is Mathematics Attitudes Scales (MAS) (Aiken 1974). Tapia and Marsh (2004) presented another option Attitudes toward Mathematics Inventory (ATMI). This instrument provides a sharp distinction between the four factors: (1) Self-confidence, (2) Value, (3) Motivation and (4) Enjoyment (Ngurah \& Lynch, 2013; Primi et al., 2020).

ATMI has high reliability and validity and many authors use the original version of this model (Asante, 2012; Guy et al., 2015; Sundre et al., 2012). Other authors have developed a shorter version of ATMI (Lim \& Chapman, 2013). In this paper, we will use the original version of ATMI with 40 items.

\section{Big Five}

The Big Five model is widely used within education (Digman, 1972; Schniederjans \& Kim, 2005). Costa and McCrae (1992) developed this five-factor model, which measures personal characteristics and includes five factors: Emotional Stability, Extraversion, Openness, Agreeableness and Conscientiousness. 
Table 2. The Big Five model (Adopted from John \& Scrivastava, 1999)

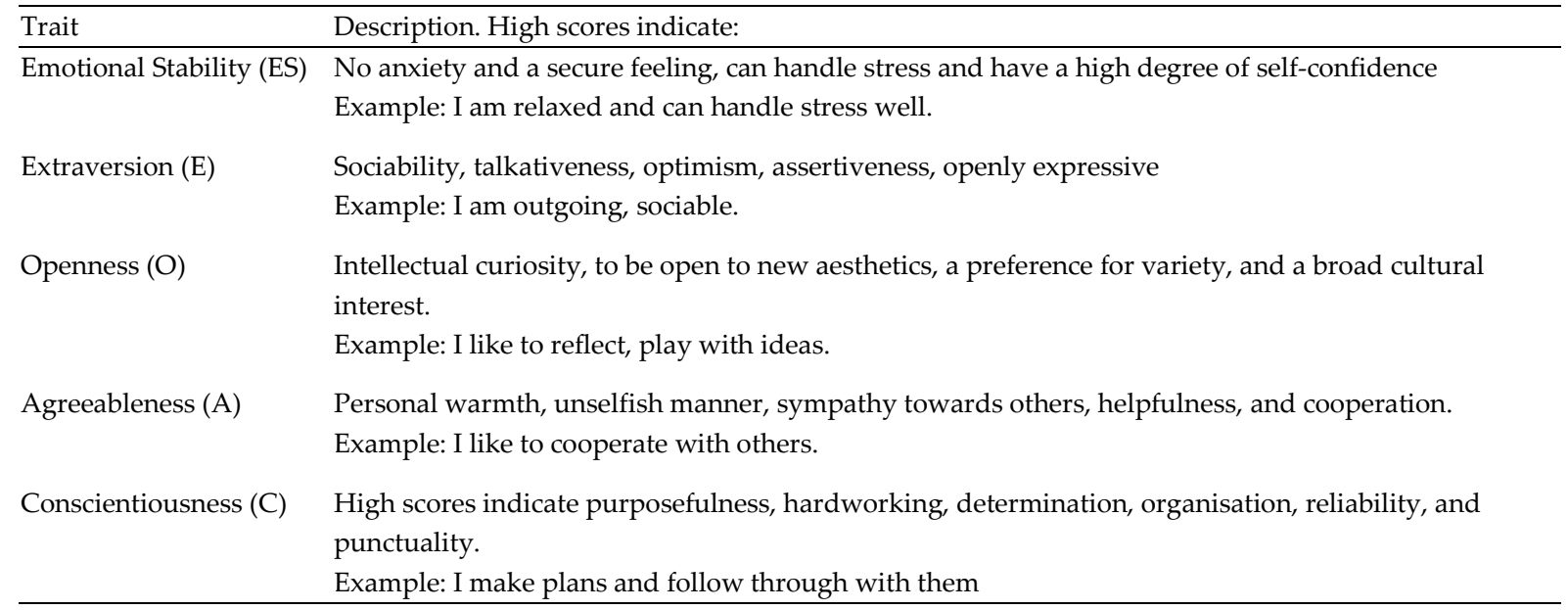

Conscientiousness and openness are particularly linked to academic success (Chamorro-Premuzic \& Furnham, 2009).

\section{LITERATURE REVIEW}

\section{Gender, Performance and Attitudes Towards Mathematics}

Several studies have demonstrated a positive correlation between student attitudes towards mathematics and performance in mathematics (Capuno et al., 2019; Elliot et al., 2001; García et al., 2016; Geesa et al., 2019; Guy et al., 2015; Lipnevich et al., 2016). There is a correlation between attitudes towards mathematics and mathematical performance (Ajisuksmo \& Saputri, 2017; Frenzel et al., 2007; Opstad, 2018). Mathematical Anxiety is a barrier to learning mathematics (Buckley et al., 2016).

Many researchers have paid attention to and explored the link between gender and performance in mathematics). The issue has been a topic for decades. Some studies report that males perform better than females (Alcock et al., 2014). One reason for this might be gender differences in attitudes towards mathematic (Frenzel et al., 2007). Using ATMI (Attitudes Towards Mathematics Inventory) scores, Asante (2012) found a significant gender gap in all four factors (Self-confidence, Enjoyment, Value and Motivation). According to Asante the girls' negative attitudes towards mathematics will probably affect their use of mathematics in the future. They may want to avoid mathematics, and this will influence their career. Important decisions might depend on student attitudes towards mathematics. The author suggests that reasons for the gender gap may include teaching style, the attitudes and beliefs of teachers and parents, the environment and student achievements and experiments that make girls feel inferior to boys. Meelissen and Luyton (2008) report that factors outside the school are important for understanding the gender differences. Cvencek et al. (2011) found a significant gender gap in attitudes towards mathematics using Dutch data, but they also found a decline over the last 40 years in the advantage held by males in mathematics. Additionally, the gender difference related to self-confidence was more substantial than that to performance in mathematics. Crombie et al. (2005) confirmed that boys believed more in using mathematics than girls, even though girls performed better in mathematical tests. Other studies confirm that men have more positive attitudes towards mathematics than women (Asante, 2012; Frenzel et al., 2007; Michelli, 2013).

The variance in performance and attitude towards mathematics between women and men are not universal (Reilly et al., 2019). Many studies do not find any significant gender difference in the attitudes towards mathematics (Batool et al., 2020; Kamoru \& Ramon, 2017; Yee, 2010; Yenilmez, 2007). Males can also be more anxious about mathematics than females (Olmez \& Ozel, 2012).

Furthermore, studies show that the gender gap in mathematical performance varies across countries (Geesa et al., 2019; Mejía-Rodríguez et al., 2020; Smith et al., 2021). In most countries, there are no 
significant gender differences. If there is a gender difference, it tends to be in favour of boys, but there are some exceptions. In some countries like Kuwait and Thailand, girls have more success than the boys in mathematics. In Sweden, girls also outperform boys in compulsory school (Brandell \& Staberg, 2008).

\section{Gender and Personal Traits}

Previous findings indicate a gender gap in personality traits (McCrae, 2002; Ock et al., 2020; Schmitt et al., 2008). This seems to be a cross-cultural phenomenon. With a sample from 55 nations ( $N=17637)$ Schmitt reported that females scored more highly than males in Agreeableness, Extraversion and Conscientiousness, while males report higher levels of Emotional stability and Openness. Gender difference in terms of preferences, personalities and interest, will influences a student's choice of studies (Cheryan \& Plaut, 2010; Dynan \& Rouse, 1997). Alcock et al. (2014) reported that personal characteristics (Big Five Model), explain the variance in mathematical achievement more than gender. When including personal traits, the gender difference in performance in mathematics disappeared. Both Conscientiousness and Openness were significantly positively correlated to achievement in mathematics.

\section{HYPOTHESIS}

The model in this research was used to identify factors which affect attitudes towards mathematics. Based on the previous literature, we postulate the following hypotheses:

Hypothesis 1 (H1): There is a gender difference in attitudes towards mathematics among business students.

Hypothesis 2 (H2): Mathematical skills and personal traits have an effect on the attitudes of business students towards mathematics.

Hypothesis 3 (H3): The gender gap in attitudes towards mathematics change when taking differences in personal characteristics and mathematical background into account.

Previous studies have documented that gender differences matter when analysing attitudes towards mathematics (H1). We want to find out if this is also the case in Norway. Personal traits and mathematical skills diverge by gender. We wonder if these factors will have an influence on the gender distinction in mathematical skills (H3). We are not aware of any previous study that has explored the gender gap in attitudes towards mathematics by connecting this issue to mathematical abilities and personal qualities.

\section{SAMPLE AND RESEARCH METHODOLOGY}

\section{The Sample}

The sample consisted of about 260 students in 2018 and 2019. Undergraduates attending a second-year compulsory macroeconomics course were asked to respond to the designed questionnaire. This ensured the students had the background required for business courses. The survey gives a picture of the opinions of the majority of the students who attended the lectures. The undergraduates were nonrandomly allocated. Around 30 percent of the students were absent from the lecture when the survey was taken. We have not estimated the representativeness of the students, however, this was done in a similar study by Bonesrønning and Opstad (2015). There were marginally more girls and a higher GPA (Grade Point Average) among the respondents than for the whole group. Approximately 30 percent of the students generally do not attend the lectures. The instruments for measuring attitudes towards mathematics and personal traits are based on methods recognised in international journals. The 20-item version of the Big-Five Inventory (BFI-20) used in this research is similar to that developed by Engvik and Clausen (2011). 


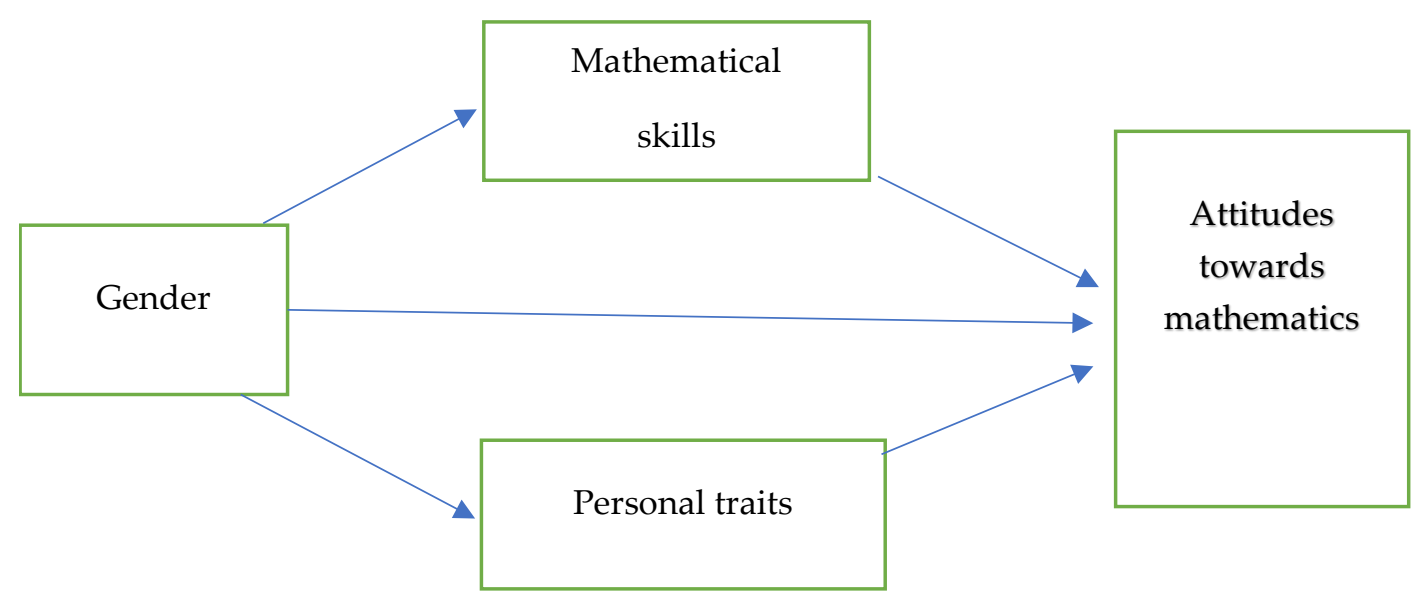

Figure 1. Gender and attitudes towards mathematics

The instrument used to measure attitudes towards mathematics (ATMI) is identical to the original version developed by Tapia and Marsh (2004).

\section{The Model}

The model's dependent variable: attitudes towards mathematics. Choosing a linear regression model makes it possible to investigate the gender impact, controlling for other factors. In this study, those components are mathematical aptitudes, and personal characteristics (See Figure 1). We used the following model:

$$
Y i=a_{0}+a_{1} X 1+a_{2} X 2+a_{3} X 3+a_{4} X 4+a_{5} X 5+a_{6} X 6+\varepsilon
$$

where

Yi: Factor i attitudes towards mathematics, i = Self-confidence, (2) Value, (3) Motivation and (4) Enjoyment (Likert scale 1 to 7, 1: strongly disagree, 7: strongly agree)

$\alpha_{0}$ : Constant

$\mathrm{X}_{1}$ : Gender (0:F, 1:M)

$\mathrm{X}_{2}$ : Dummy variable for $\mathrm{N}$-mathematics (0: Non $\mathrm{N}$-maths, 1 : $\mathrm{N}$-maths)

$\mathrm{X}_{3}$ : Agreeableness (Likert scale 1 to 5, 1: strongly disagree, 5: strongly agree)

$\mathrm{X}_{4}$ : Conscientiousness (Likert scale 1 to 5, 1: strongly disagree, 5: strongly agree)

$\mathrm{X}_{5}$ : Extraversion (Likert scale 1 to 5, 1: strongly disagree, 5: strongly agree)

$\mathrm{X}_{6}$ : Neuroticism (Likert scale 1 to 5, 1: strongly disagree, 5: strongly agree)

$\varepsilon$ : stochastic error

One way to distinguish between direct and indirect gender impact is to put different sets of independent variables in the regression model. Step 1 includes only gender as an independent variable, Step 2 adds gender and personal traits, and finally Step 3 includes all six independent variables. Step 3 will thus control for other elements, and the difference between Steps 1 and 3 indicates the indirect impact (of personal traits and mathematical abilities).

Since there is no access to experimental data, one should be careful to conclude about causal relationships. 
Table 3. Descriptive statistics

\begin{tabular}{lcccccccccc}
\hline & $\mathrm{N}$ & Min & Max & Mean & Std. dev Skewness & $\begin{array}{c}\text { Std. } \\
\text { Error }\end{array}$ & Kurtosis & $\begin{array}{c}\text { Std. } \\
\text { Error }\end{array}$ & $\begin{array}{c}\text { Scale Reliability } \\
\text { Cronbach's } \\
\text { Alpha }\end{array}$ \\
\hline Gender (0: Female, 1: Male) & 242 & .00 & 1.00 & .4500 & .49800 & .217 & .156 & -1.969 & .312 & \\
N-mathematics & 258 & .00 & 1.00 & .3256 & .46950 & .749 & .152 & -1.451 & .302 & \\
\hline Attitudes towards Mathematics: & & & & & & & & & & .916 \\
Self-confidence & 258 & 1.59 & 6.65 & 5.0356 & 1.06222 & -.744 & .152 & .276 & .302 & .832 \\
Value & 258 & 2.38 & 7.00 & 5.0208 & .94823 & -.402 & .152 & -.056 & .302 & .835 \\
Motivation & 258 & 1.29 & 7.00 & 4.8067 & 1.12163 & -.280 & .152 & -.135 & .302 & .807 \\
Enjoyment & 258 & 1.00 & 7.00 & 4.5468 & 1.25360 & -.205 & .152 & -.376 & .302 & \\
Big Five: & & & & & & & & & & \\
Agreeableness & 256 & 1.75 & 5.00 & 3.9827 & .54573 & -.798 & .152 & 1.317 & .303 & .608 \\
Conscientiousness & 257 & 1.50 & 5.00 & 3.7143 & .66973 & -.598 & .152 & .381 & .303 & .696 \\
Extraversion & 257 & 1.50 & 5.00 & 3.6637 & .73256 & -.290 & .152 & -.255 & .303 & .816 \\
Openness & 256 & 1.25 & 5.00 & 3.3079 & .70553 & -.031 & .152 & -.275 & .303 & .565 \\
Emotional Stability & 257 & 1.50 & 5.00 & 3.3732 & .74685 & -.059 & .152 & -.440 & .303 & .727 \\
Valid N (listwise) & 240 & & & & & & & & & \\
\hline
\end{tabular}

Table 4. Coefficient Correlations

\begin{tabular}{|c|c|c|c|c|c|c|c|c|c|c|c|}
\hline & 1 & 2 & 3 & 4 & 5 & 6 & 7 & 8 & 9 & 10 & 11 \\
\hline 1 & 1 & .522 & .815 & $\begin{array}{l}.731 \\
\end{array}$ & .318 & $\begin{array}{l}-011 \\
\end{array}$ & -.012 & $\begin{array}{l}.024 \\
\end{array}$ & .123 & -.124 & -.036 \\
\hline 2 & .522 & 1 & .731 & .711 & .203 & .018 & -.097 & .076 & .020 & .044 & .002 \\
\hline 3 & .815 & .731 & 1 & .878 & .260 & .005 & -.043 & .012 & .064 & -.053 & -.052 \\
\hline 4 & .731 & .711 & .878 & 1 & .282 & -.052 & -.110 & .004 & -.003 & -.062 & -.042 \\
\hline 5 & .318 & .203 & .260 & .282 & 1 & -.077 & -.002 & .049 & .034 & -.021 & .060 \\
\hline 6 & -.011 & .018 & .005 & -.052 & -.077 & 1 & .207 & -.047 & .268 & .219 & -.104 \\
\hline 7 & -.012 & -.097 & -.043 & -.110 & -.002 & .207 & 1 & .248 & .000 & -.101 & -.155 \\
\hline 8 & .024 & .076 & .012 & .004 & .049 & -.047 & .248 & 1 & -.091 & -.243 & -.137 \\
\hline 9 & .123 & .020 & .064 & -.003 & .034 & .268 & .000 & -.091 & 1 & .204 & .419 \\
\hline 10 & -.124 & .044 & -.053 & -.062 & -.021 & .219 & -.101 & -.243 & .204 & 1 & .192 \\
\hline 11 & -.036 & .002 & -.052 & -.042 & .060 & -.104 & -.155 & -.137 & .419 & .192 & 1 \\
\hline
\end{tabular}

1.Self-confidence 2. Value 3. Motivation 4. Enjoyment 5. N-math 6. Extraversion 7. Agreeableness 8. Conscientiousness 9. Emotional Stability 10. Openness 11. Gender

\section{The Data}

Men were in the minority in the sample (45 percent, see Table 2). Note the high scores measuring attitudes towards mathematics among the business students. Using a 7-point Likert scale, the values for the factors are around 5.0, with lowest score for Enjoyment (4.5).

There are rather small variations in the value of the dimension for the Big Five (using a 5-point Likert scale) The lowest value is 3.3 (Openness) and the highest value 4.0 (Agreeableness). We have not carried out our own factor analysis to measure ATMI and the Big Five. Scores from the components using these items have been carefully validated worldwide. Note also that the scores for scale reliability (Cronbach's Alpha) are within acceptable values, except for the Openness dimension, which is slightly below the desired limit of 0.6. The values of skewness and kurtosis are within critical limits.

Table 4 shows the correlation coefficient between the variables. It provides useful information that will be analysed more closely later. As an example, gender is positively correlated with factors measuring the Big Five, but not with the dimensions that capture attitudes towards mathematics. The effects are the opposite for the Mathematical Background variable. There is a positive connection between mathematical abilities and attitudes towards mathematics, but not between mathematical personalities and personal traits. Gender is positively correlated to mathematical skills, since N-mathematics tends to be more popular among male students (see Table 5). 
Table 5. Gender and choice of mathematics from upper secondary school

\begin{tabular}{lccc}
\hline & Female & Male & \\
\hline Non N-maths & 92 & 68 & 160 \\
N-maths & 42 & 40 & 82 \\
\hline Total & 134 & 108 & 242 \\
\hline
\end{tabular}

Table 6. Differences in gender and mathematical skills, independent t-test

\begin{tabular}{lcccccc}
\hline & \multicolumn{3}{c}{ Gender } & \multicolumn{3}{c}{ Mathematical skills } \\
\hline $\begin{array}{l}\text { Attitudes towards } \\
\text { mathematics: }\end{array}$ & $\begin{array}{c}\text { Female } \\
(\mathrm{N}=136)\end{array}$ & $\begin{array}{c}\text { Male } \\
(\mathrm{N}=110)\end{array}$ & Difference & $\begin{array}{c}\text { N-maths } \\
(\mathrm{N}=84)\end{array}$ & $\begin{array}{c}\text { Non N-maths } \\
(\mathrm{N}=178)\end{array}$ & Difference \\
\hline Self-confidence & 5.06 & 5.01 & 0.05 & 5.52 & 4.78 & $0.74^{* * *}$ \\
Value & 5.03 & 5.04 & 0.01 & 5.30 & 4.87 & $0.43^{* * *}$ \\
Motivation & 4.86 & 4.78 & 0.08 & 5.23 & 4.60 & $0.63^{* * *}$ \\
Enjoyment & 4.62 & 4.52 & 0.10 & 5.05 & 4.30 & $0.75^{* * *}$ \\
\hline Big Five: & & & & & 3.96 & -0.02 \\
\hline Agreeableness & 4.05 & 3.88 & $0.17^{* * *}$ & 3.94 & 3.69 & 0 \\
Conscientiousness & 3.81 & 3.59 & $0.22^{* *}$ & 3.69 & 3.67 & -0.06 \\
Extraversion & 3.71 & 3.58 & 0.13 & 3.61 & 3.23 & 0 \\
Openness & 3.14 & 3.39 & $-0.24^{* *}$ & 3.23 & 3.32 & $0.18^{*}$ \\
Emotional Stability & 3.07 & 3.68 & $-.61^{* * *}$ & 3.50 &
\end{tabular}

Notes: ${ }^{*}, * *$, and ${ }^{* * *}$ denote significant level at $5 \%, 1 \%$ and $0.1 \%$ respectively (Independent Samples t-test)

\section{FINDINGS}

\section{Descriptive Difference in Gender and Mathematical Skills, Pairwise Companionship Using T-test}

This research shows a significant connection between gender and personal traits, but not between gender and attitudes towards statistics (ATMI). None of the four dimensions (Self-confidence, Value, Motivation or Enjoyment) showed any significant gender difference. Those factors were all significant with comparing those with or without N-mathematics from upper secondary school. There is a strong positive relationship between mathematical background and attitudes towards mathematics. On the other hand, the link between mathematical abilities and personal traits is rather week. Only the factor Emotional Stability had a significant impact at the 5 percent level.

\section{Results from the Regression Model}

The regression analysis shows a strong positive correlation between mathematical background and attitudes towards mathematics for all four dimensions. The standardised Beta values are around 0.3, except for Value of Mathematics where the score is 0.233. This is in line with the findings from the pairwise comparison. The relationships between personal traits and attitudes towards mathematics are more mixed. Contrary to the paired difference, the regression models show significant effects for several of the variables. There is a strong link between Emotional Stability and Self-confidence in Mathematics, with Beta values almost the same as for Mathematical Skills. There is also a significantly strong connection between Emotional Stability and Motivation for Mathematics. Consciousness is significantly positively associated with Value of Mathematics. Finally, Agreeableness is negatively related to all factors, where two are statistical significant at 10 percent level (Step 3). In summary, we can claim that Hypothesis 2 is valid.

The gender effect on attitudes towards mathematics is not so strong. The Beta values for the total effect are small and not significant at all. This is in line with the results from the pairwise observations (Table 6). On the other hand, there are some significant results for the direct effect, but only at a 10 percent level (Self-confidence and Motivation for Mathematics). The standardised beta values are negative for both. This means the females had more positive attitudes towards mathematics than the males. The results only partially confirm Hypothesis H1. Table 7 shows the change in the significance level from direct to total effect for Self-confidence and Motivation. This confirms Hypothesis H3. 
Table 7. Results from the Regression Model: Attitudes towards Mathematics (Standardised coefficient Beta)

\begin{tabular}{|c|c|c|c|c|c|c|c|c|}
\hline & \multicolumn{2}{|c|}{ Self-confidence } & \multicolumn{2}{|c|}{ Value } & \multicolumn{2}{|c|}{ Motivation } & \multicolumn{2}{|c|}{ Enjoyment } \\
\hline & Beta & Significance & Beta & Significance & Beta & Significance & Beta & Significance \\
\hline & & Level & & Level & & Level & & Level \\
\hline \multicolumn{9}{|l|}{ Step 1} \\
\hline \multirow[t]{2}{*}{ Gender } & -0.220 & 0.730 & 0.040 & 0.950 & -0.036 & 0.600 & -0.042 & 0.520 \\
\hline & \multicolumn{2}{|c|}{$\begin{array}{c}\mathrm{N}=245, \\
\text { Adj. } \mathrm{R}^{2}=0.0\end{array}$} & \multicolumn{2}{|c|}{$\begin{array}{c}\mathrm{N}=245, \\
\text { Adj. } \mathrm{R}^{2}=0.0\end{array}$} & \multicolumn{2}{|c|}{$\begin{array}{c}\mathrm{N}=245, \\
\text { Adj. } \mathrm{R}^{2}=0.0\end{array}$} & \multicolumn{2}{|c|}{$\begin{array}{c}\mathrm{N}=245, \\
\text { Adj. } \mathrm{R}^{2}=0.0\end{array}$} \\
\hline \multicolumn{9}{|l|}{ Step 2} \\
\hline Gender & -0.123 & 0.092 & -0.043 & 0.556 & -0.128 & 0.084 & -0.102 & 0.176 \\
\hline Agreeableness & -0.011 & 0.875 & -0.112 & 0.103 & -0.047 & 0.497 & -0.114 & 0.101 \\
\hline Conscien-tiousness & 0.042 & 0.534 & 0.168 & 0.015 & 0.049 & 0.469 & 0.045 & 0.515 \\
\hline Extraversion & -0.103 & 0.147 & -0.014 & 0.850 & -0.070 & 0.329 & -0.081 & 0.269 \\
\hline Openness & -0.096 & 0.160 & 0.080 & 0.246 & -0.041 & 0.557 & -0.030 & 0.668 \\
\hline \multirow[t]{2}{*}{ Emotional Stability } & 0.272 & 0.000 & 0.093 & 0.217 & 0.218 & 0.004 & 0.108 & 0.159 \\
\hline & \multicolumn{2}{|c|}{$\begin{array}{c}\mathrm{N}=243 \\
\text { Adj. } \mathrm{R}^{2}=0.040\end{array}$} & \multicolumn{2}{|c|}{$\begin{array}{c}\mathrm{N}=243 \\
\text { Adj. } \mathrm{R}^{2}=0.014\end{array}$} & \multicolumn{2}{|c|}{$\begin{array}{c}\mathrm{N}=243 \\
\text { Adj. } \mathrm{R}^{2}=0.016\end{array}$} & \multicolumn{2}{|c|}{$\begin{array}{c}\mathrm{N}=239 \\
\text { Adj. } \mathrm{R}^{2}=0.003\end{array}$} \\
\hline \multicolumn{9}{|l|}{ Step 3} \\
\hline Gender & -0.126 & 0.067 & -0.046 & 0.525 & -0.131 & 0.066 & -0.107 & 0.360 \\
\hline N-maths & 0.331 & 0.000 & 0.233 & 0.000 & 0.278 & 0.000 & 0.304 & 0.000 \\
\hline Agreeableness & -0.012 & 0.847 & -0.113 & 0.092 & -0.048 & 0.466 & -0114 & 0.086 \\
\hline Conscientiousness & 0.021 & 0.741 & 0.154 & 0.022 & 0.032 & 0.628 & 0.029 & 0.662 \\
\hline Extraversion & -0.070 & 0.300 & 0.009 & 0.898 & -0.042 & 0.544 & -0.053 & 0.451 \\
\hline Openness & -0.100 & 0.122 & 0.078 & 0.248 & -0.044 & 0.512 & -0.031 & 0.649 \\
\hline \multirow[t]{2}{*}{ Emotional Stability } & 0.241 & 0.001 & 0.072 & 0.328 & 0.192 & 0.008 & 0.083 & 0.257 \\
\hline & \multicolumn{2}{|c|}{$\begin{array}{c}\mathrm{N}=243 \\
\text { Adj. } \mathrm{R}^{2}=0.147\end{array}$} & \multicolumn{2}{|c|}{$\begin{array}{c}N=243 \\
\text { Adj. } R^{2}=0.060\end{array}$} & \multicolumn{2}{|c|}{$\begin{array}{c}\mathrm{N}=243, \\
\text { Adj. } \mathrm{R}^{2}=0.090\end{array}$} & \multicolumn{2}{|c|}{$\begin{array}{c}\mathrm{N}=239 \\
\text { Adj. } \mathrm{R}^{2}=0.092\end{array}$} \\
\hline
\end{tabular}

Notes: Variance inflation factors are between 1.0 and 2.0

Table 8. Direct and indirect gender relationships to attitudes towards mathematics

\begin{tabular}{lcccc}
\hline & $\begin{array}{c}\text { Direct (Step 3, Beta- } \\
\text { values, Table 5 }\end{array}$ & $\begin{array}{c}\text { Indirect (Difference } \\
\text { between step 1 and 3) }\end{array}$ & $\begin{array}{c}\text { Total (Step 1, Beta-values, } \\
\text { Table 5) }\end{array}$ & $\begin{array}{c}\text { Significance Level, Change } \\
\text { from Direct to Total }\end{array}$ \\
\hline Self-confidence & -0.126 & 0.094 & -0.220 & $6.7 \%$ to $73 \%$ \\
Value & -0.046 & -0.086 & 0.040 & $52.5 \%$ to $95 \%$ \\
Motivation & -0.131 & -0.095 & -0.036 & $6.6 \%$ to $60.0 \%$ \\
Enjoyment & -0.107 & 0.065 & -0.042 & $36 \%$ to $52 \%$ \\
\hline
\end{tabular}

\section{DISCUSSION}

There is a global attention about students' attitudes towards mathematics and their achievement in sciences (Geesa et al., 2019). Much of the finding in this study is in line with prior research.

\section{Gender and Attitudes}

Looking at the total effect, the results indicate no relationship between gender and attitude towards mathematics. Prior research is mixed about this issue. Many studies report that the gender gaps in performance and attitudes towards mathematics have decreased over time. The current overall gender differences are negligible, internationally (Baird \& Keene, 2019) In an earlier study among undergraduate business and economics students at the Norwegian University of Science and Technology a weak gender difference was found in favour of males among the business students, but not among the economics students (Opstad \& Årethun, 2019). Updated data indicates the same result for undergraduate business students as for economics students. The results show no gender differences in attitudes towards mathematics. In Norway, boys have traditionally been more interested in mathematics and have achieved better results. This has changed. Educational institutions in Norway have prioritised strengthening the position of mathematics and science among pupils (at primary school 
and upper secondary school). In Norway, the Pisa test of 2018 reported higher student scores in mathematics than on average in OECD countries (OECD Education, 2020). Furthermore, girls performed better than boys. Medical studies require good scores and mathematical skills from upper secondary school. Traditionally, these studies have been male dominated, but not anymore. Girls perform well and the proportion of women in medical schools has increased, and it is now 70 percent (Hovdhaugen et al., 2020). Utvær (2019) reports no gender difference among pupils in primary schools in attitudes towards mathematics. Taking into account the development in Norway in recent decades, in which the position of women has strengthened, the results of this analysis are not surprising. Analysing the total gender impact means that we can conclude that Hypothesis 1 (H1) is rejected. There is no gender difference in attitudes towards mathematics (Step 1 in the regression model).

\section{Mathematical Background and Attitudes}

There is a very strong and substantial connection between mathematical background and attitudes towards mathematics (see Tables 6 and 7). This is consistent with previous research. Students with mathematical skills have a more positive attitude towards mathematics. Students who choose theoretical mathematics at upper secondary school tend to perform well in mathematics and are interested in this subject (Opstad, 2019). Many students who have positive attitudes towards mathematics decide to learn more about this subject. The links therefore probably go both ways. Positive attitudes towards mathematics improve mathematical skills, and this will increase positive attitudes towards this subject. Our findings show a strong significant relationship between mathematical skills and attitudes towards mathematics. Although girls perform well in mathematics at upper secondary school, among the business students more girls than boys choose practical mathematics (see Table 5).

\section{Personality Traits and Attitudes}

The regression models show that mathematical background has a much stronger impact on attitudes towards mathematics than personal traits. In line with other research this model reveals a significant positive relationship between conscientiousness and value of mathematics $(\beta=0.154, p<0.022)$. Consistent with prior research it shows that hard-working and achievement-oriented undergraduates put a great deal of effort into learning mathematics. Conscientiousness is a good indicator of academic performance. This explains the relationship between this factor and attitudes towards mathematics, since mathematics is an important tool for success in business courses (Opstad, 2018). There is also a strong significant positive link between Emotional Stability and the two factors Self-confidence $(\beta=$ $0.241, \mathrm{p}<0.001)$ and Motivation for Mathematics. $(\beta=0.192, \mathrm{p}<0.008)$. According to prior research, this is not surprising, since anxiety is negatively correlated with performance in mathematics (Namkung et al., 2019). Absence of anxiety results in higher motivation and continued learning. inverse of emotional stability). Furthermore, there is a weak negative significant association between Agreeableness and some of the dimensions measuring attitudes towards mathematics (Value and Enjoyment). Brandt et al. (2020) reported a negative correlation between Agreeableness and success in mathematics. It makes sense that Agreeableness is also negative linked to attitudes towards mathematics. Both Value $(\beta=-$ 0.113, $\mathrm{p}<0.092)$ and Enjoyment $(\beta=-0.114, \mathrm{p}<0.086)$ are weakly negatively correlated with Agreeableness.

There is a gender gap in personal traits. The findings in this research are in line with prior investigations. The pairwise comparisons (see Table 6) reveal that males have higher scores in Openness and Emotional Stability, while females have higher values in Agreeableness and Conscientiousness. This will have an effect on the direct gender influence on attitudes towards mathematics. Furthermore, personal traits can explain the deviation in student attitudes towards mathematics to a higher degree than gender. This is consistent with the results of Alcock et al. (2014). 


\section{Contribution}

The main contribution of this paper is to simultaneously consider gender, mathematical background and personal characteristics in the analysis of student attitudes towards mathematics. Controlling for mathematical background and personal traits, it turns out that the females achieve higher scores than their male peers. Including mathematical background and personal characteristics means that the gender difference changes from no impact to a weak difference in favour of girls (see Table 8). This is an interesting result. Women dominate higher education in Norway, and they perform well in many fields. They are recruited to attractive positions in the public and business sectors. This has probably helped to change the self-confidence and attitudes towards mathematics of female students, since the findings in this research suggest that among undergraduate business students, females today have at least the same positive attitudes towards mathematics as their male peers.

\section{LIMITATIONS}

The dataset in this study is from only one business school in Norway, and therefore it is not possible to say how valid the results are in an international context. The $\mathrm{R}$ square values are rather low, and therefore, there are probably other important factors which may explain the undergraduates' attitudes towards mathematics. This research uses the original version of attitudes towards mathematics (ATMI). Higher scores of goodness-of-fit can be achieved by conducting an explanatory factor analysis and presenting an adjusted version of ATMI. In line with many other authors, this method was not considered here since the original version of the ATMI is commonly applied internationally.

The survey is based on a compulsory introductory course in mathematics for business students. It is difficult to say what result one would have received if one had asked students who have taken more theoretical courses in mathematics.

\section{CONCLUSIONS}

Traditionally, there has been a gender difference in attitudes and performance in mathematics, where males outperform their female peers. Many authors have reported that this effect has declined over time. This study suggests there is no gender gap in attitudes towards mathematics among undergraduate business students in Norway. Adjusting for mathematical background and personal traits, the gender difference seems to be in favour of females. The impact is weak and only significant at the 10 percent level, but nevertheless, this is an interesting result. Mathematics is important for success in business studies. Since women have positive attitudes towards mathematics, this might have an impact on gender differences among business students. More females might choose theoretical mathematics in upper secondary school and this will probably affect their selection of major courses. The majority of the students in finance are still male, however (Opstad \& Årethun, 2020). Mathematics is an important tool in finance subjects and if more women choose advanced mathematics it is likely to affect the gender distribution. This is a subject for further studies. Hopefully, this article contributes by offering more insight into the topic of gender and attitudes towards mathematics. The simultaneous analysis of how mathematical background, personal characteristics and gender influence attitudes towards mathematics is an important contribution.

Funding: Author received no financial support for the research and/or authorship of this article.

Declaration of interest: Author declared no competing interest.

Data availability: Data generated or analysed during this study are available from the author on request.

\section{REFERENCES}

Aiken, L. R. (1974). Two scales of attitude toward mathematics. Journal for research in Mathematics Education, 5(2), 6771. https://doi.org/10.5951/jresematheduc.5.2.0067

Ajisuksmo, C. R. P., \& Saputri, G. R. (2017). The influence of attitudes towards mathematics, and metacognitive awareness on mathematics achievements. Creative Education, 8(3), 486-497. https://doi.org/10.4236/ce.2017.83037 
Alcock, J., Cockcroft, S., \& Finn, F. (2008). Quantifying the advantage of secondary mathematics study for accounting and finance undergraduates. Accounting and Finance, 48(5), 697-718. https://doi.org/10.1111/j.1467-629X.2008.00261

Alcock, L., Attridge, N., Kenny, S., \& Inglis, M. (2014). Achievement and behaviour in undergraduate mathematics: personality is a better predictor than gender. Research in Mathematics Education, 16(1), 1-17. https://doi.org/10.1080/14794802.2013.874094

Asante, K. O. (2012) Secondary students' attitudes towards mathematics. IFE Psychologia, An International Journal, 20(1), 121-133.

Baird, C. L., \& Keene, J. R. (2019). Closing the gender gap in math confidence: Gender and race/ethnic similarities and differences. International Journal of Gender, Science and Technology, 10(3), 378-410.

Batool, T., Akhter, S., \& Kalsoom, T. (2020). Exploring Gender differences in attitude towards Mathematics at Secondary Level in Pakistan. Journal of Business and Social Review in Emerging Economies, 6(2), 587-596. https://doi.org/10.26710/jbsee.v6i2.1157

Bonesrønning, H., \& Opstad, L. (2015). Can student effort be manipulated? Does it matter? Applied Economics, 47(15), 1511-1524. https://doi.org/10.1080/00036846.2014.997923

Brandell, G., \& Staberg, E. M. (2008). Mathematics: A female, male or gender-neutral domain? A study of attitudes among students at secondary level. Gender and Education, 20(5), 495-509. https://doi.org/10.1080/09540250701805771

Brandt, N. D., Lechner, C. M., Tetzner, J., \& Rammstedt, B. (2020). Personality, cognitive ability, and academic performance: Differential associations across school subjects and school tracks. Journal of personality, 88(2), 249-265. https://doi.org/10.1111/jopy.12482

Buckley, S., Reid, K., Goos, M., Lipp, O. V., \& Thomson, S. (2016). Understanding and addressing mathematics anxiety using perspectives from education, psychology and neuroscience. Australian Journal of Education, 60(2), 157-170. https://doi.org/10.1177/0004944116653000

Capuno, R., Necesario, R., Etcuban, J. O., Espina, R., Padillo, G., \& Manguilimotan, R. (2019). Attitudes, Study Habits, and Academic Performance of Junior High School Students in Mathematics. International Electronic Journal of Mathematics Education, 14(3), 547-561. https://doi.org/10.29333/iejme/5768

Chamorro-Premuzic, T., \& Furnham, A. (2009). Mainly Openness: The relationship between the Big Five personality traits and learning approaches. Learning and individual Differences, 19(4), 524-529. https://doi.org/10.1016/j.lindif.2009.06.004

Cheryan, S., \& Plaut, V. C. (2010). Explaining underrepresentation: A theory of precluded interest. Sex roles, 63(7), 475-488. https://doi.org/10.1007/s11199-010-9835-x

Costa Jr, P. T., \& McCrae, R. R. (1992). Professional manual, Revised NEO personality inventory (NEO-PI-R) and NEO five-factor inventory (NEO-FFI). Odessa, FL: Psychological Assessment Resources.

Crombie, G., Sinclair, N., Silverthorn, N., Byrne, B. M., DuBois, D. L., \& Trinneer, A. (2005). Predictors of young adolescents' math grades and course enrollment intentions: Gender similarities and differences. Sex Roles, 52(5), 351-367. https://doi.org/10.1007/s11199-005-2678-1

Cvencek, D., Meltzoff, A. N., \& Greenwald, A. G. (2011). Math-gender stereotypes in elementary school children. Child development, 82(3), 766-779. https://doi.org/10.1111/j.1467-8624.2010.01529.x

Digman, J. M. (1972) High school academic achievement as seen in the context of a longitudinal study of personality. Proceedings of the Annual Convention of the American Psychological Association. American Psychological Association, Honolulu, Hawaii, USA.

Dynan, K. E., \& Rouse, C.E. (1997). The underrepresentation of women in economics, A study of undergraduate economics students. The Journal of Economic Education, 28(4), 350-368. https://doi.org/10.1080/00220489709597939

Elliott, B., Oty, K., McArthur, J., \& Clark, B. (2001). The effect of an interdisciplinary algebra/science course on students' problem solving skills, critical thinking skills and attitudes towards mathematics. International Journal of mathematical education in science and technology, 32(6), 811-816. https://doi.org/10.1080/00207390110053784

Engvik, H., \& Clausen, S. (2011). Norsk kortversjon av big five inventory (BFI-20). Tidsskrift for norsk psykologforening, 48(9), 869872. (In Norwegian).

Fennema, E., \& Sherman, J.A. (1976). Fennema-Sherman mathematics attitudes scales, Instruments designed to measure attitudes toward the learning of mathematics by females and males. Journal for Research in Mathematics Education, 7(5), 324-326. https://doi.org/10.2307/748467

Frenzel, A. C., Pekrun, R., \& Goetz, T. (2007). Girls and mathematics-A “hopeless" issue? A control-value approach to gender differences in emotions towards mathematics. European Journal of Psychology of Education, 22(4), 497-514. https://doi.org/10.1007/bf03173468

García, T., Rodríguez, C., Betts, L., Areces, D., \& González-Castro, P. (2016). How affective-motivational variables and approaches to learning predicts mathematics achievement in upper elementary levels. Learning and Individual Differences, 49, 25-31. https://doi.org/10.1016/j.lindif.2016.05.021

Geesa, R. L., Izci, B., Song, H., \& Chen, S. (2019). Exploring factors of home resources and attitudes towards mathematics in mathematics achievement in South Korea, Turkey, and the United States. EURASIA Journal of Mathematics, Science and Technology Education, 15(9), em1751. https://doi.org/10.29333/ejmste/108487 
Guy, G. M., Cornick, J., \& Beckford, I. (2015). More than math: on the affective domain in developmental mathematics. International journal for the scholarship of teaching and learning, 9(2), n2. https://doi.org/10.20429/ijsotl.2015.090207

Hemmings, B., \& Kay, R. (2010). Prior achievement, effort, and mathematics attitude as predictors of current achievement. The Australian Educational Researcher, 37(2), 41-58. https://doi.org/10.1007/BF03216921

Hovdhaugen, E., Sandsør, A. M. J., Rønsen, E., \& Carlsten, T. C. (2020). Opptak til høyere utdanning: En studie av konsekvensene av kvote og poengberegning med fokus på psykologi, medisin, jus og grunnskolelærer-utdanning [Admission to higher education: A study of the consequences of quota and point calculation with a focus on psychology, medicine, law and primary school teacher education]. NIFU-rapport, 2020, 4. (2020) (In Norwegian).

John, O. P., \& Srivastava, S. (1999). The Big Five Trait taxonomy: History, measurement, and theoretical perspectives. In L. A. Pervin \& O. P. John (Eds.), Handbook of personality: Theory and research (p. 102-138). Guilford Press.

Kamoru, U., \& Ramon, O.G. (2017). Influence of self-concept, study habit and gender on attitude and achievement of secondary school students in mathematics. Journal for Leadership and Instruction, 16(1), 49-52.

Larson, L. M., Wu, T. F., Bailey, D. C., Borgen, F. H., \& Gasser, C. E. (2010). Male and female college students' college majors: The contribution of basic vocational confidence and interests. Journal of Career Assessment, 18(1), 16-33. https://doi.org/10.1177/1069072709340520

Lim, S. Y., \& Chapman, E. (2013). Development of a short form of the attitudes toward mathematics inventory. Educational Studies in Mathematics, 82(1), 145-164. https://doi.org/10.1007/s10649-012-9414-x

Lipnevich, A. A., Preckel, F., \& S. Krumm, S. (2016). Mathematics attitudes and their unique contribution to achievement: Going over and above cognitive ability and personality. Learning and Individual Differences, 47, 70-79. https://doi.org/10.1016/j.lindif.2015.12.027

Marbán, J. M., \& Mulenga, E. M. (2019). Pre-Service Primary Teachers' Teaching Styles and Attitudes towards the Use of Technology in Mathematics Classrooms. International Electronic Journal of Mathematics Education, 14(2), 253-263. https://doi.org/10.29333/iejme/5649

McCrae, R. R. (2002). NEO-PI-R data from 36 cultures. In R. R. McCrae \& J. Allik (Eds.), The five-factor model of personality across cultures (pp. 105-126). Kluwer Academic/Plenum Publishers.

Meelissen, M., \&. Luyten, H. (2008). The Dutch gender gap in mathematics: Small for achievement, substantial for beliefs and attitudes. Studies in Educational Evaluation, 34(2), 82-93. https://doi.org/10.1016/j.stueduc.2008.04.004

Mejía-Rodríguez, A. M., Luyten, H., \& Meelissen, M. R. (2020). Gender Differences in Mathematics Self-Concept Across the World: an Exploration of Student and Parent Data of TIMSS 2015. International Journal of Science and Mathematics Education, 1-22. https://doi.org/10.1007/s10763-020-10100-x

Michelli, M. P. (2013). The relationship between attitudes and achievement in mathematics among fifth grade students (Honors Thesis), The University of Sothern Mississippi, USA

Namkung, J. M., Peng, P., \& Lin, X. (2019). The relation between mathematics anxiety and mathematics performance among school-aged students: a meta-analysis. Review of Educational Research, 89(3), 459-496. https://doi.org/10.3102/0034654319843494

Ngurah, A. A. M. I. G., \& Lynch, D. P. (2013). A confirmatory factor analysis of attitudes toward mathematics inventory (ATMI). The Mathematics Educator, 15(1), 121-135.

Ock, J., McAbee, S. T., Mulfinger, E., \& Oswald, F. L. (2020). The practical effects of measurement invariance: Gender invariance in two Big Five personality measures. Assessment, 27(4), 657-674. https://doi.org/10.1177/1073191119885018

OECD Education (2020). Norway, Student performance Pisa 2018. Retrieved from https://gpseducation.oecd.org/CountryProfile?primaryCountry=NOR\&treshold=10\&topic=PI

Olmez, I. B., \& Ozel, S. (2012). Mathematics anxiety among sixth and seventh grade Turkish elementary school students. ProcediaSocial and Behavioral Sciences, 46, 4933-4937. https://doi.org/10.1016/j.sbspro.2012.06.362

Opstad, L. (2018). Success in business studies and mathematical background, The case of Norway. Journal of Applied Research in Higher Education, 10(3), 399-408. https://doi.org/10.1108/JARHE-11-2017-0136

Opstad, L. (2019). Different attitudes towards mathematics among economic and business students and choice of business course major in Norway. Social Sciences and Education Research Review, 6(2), 6-30.

Opstad, L., \& Årethun. T.(2019). Attitude towards mathematics among economics and business students in Norway. Is there any gender difference? [Paper Presentation]. Proceedings of the 16th International Conference on Enterprises, Systems, Accounting, Logistics and Management (16th ICESALM 2019). Chania, Crete, Greece.

Opstad, L., \& Årethun. T.(2020). Factors that explain undergraduate business students' performance in their chosen field. Does gender matter? Global Conference on Business and Finance Proceedings, 15(2), 2-21.

Pepin, B. (2011). Pupils' attitudes towards mathematics, A comparative study of Norwegian and English secondary students. ZDM Mathematical Education, 43(4), 535-546. https://doi.org/10.1007/s11858-011-0314-9

Primi, C., Bacherini, A., Beccari, C., \& Donati, M. A. (2020). Assessing math attitude through the Attitude Toward Mathematics Inventory-Short form in introductory statistics course students. Studies in Educational Evaluation, 64, 100838. https://doi.org/10.1016/j.stueduc.2020.100838 
Recber, S., Isiksal, M., \& Koç, Y. (2018). Investigating self-efficacy, anxiety, attitudes and mathematics achievement regarding gender and school type. Anales de Psicología/Annals of Psychology, 34(1), 41-51. https://doi.org/10.6018/analesps.34.1.229571

Reilly, D., Neumann, D. L., \& Andrews, G. (2019). Investigating gender differences in mathematics and science: Results from the 2011 Trends in Mathematics and Science Survey. Research in Science Education, 49(1), 25-50. https://doi.org/10.1007/s11165017-9630-6

Schaeffer, M. W., Rozek, C. S., Maloney, E. A., Berkowitz, T., Levine, S. C., \& Beilock, S. L. (2020). Elementary school teachers' math anxiety and students' math learning, A large-scale replication. Developmental Science, e13080. https://doi.org/10.1111/desc.13080

Schmitt, D. P., Realo, A., Voracek, M., \& Allik, J. (2008). Why can't a man be more like a woman? Sex differences in Big Five personality traits across 55 cultures. Journal of personality and social psychology, 94(1), 168. https://doi.org/10.1037/00223514.94.1.168

Schniederjans, M. J., \& Kim, E. B. (2005). Relationship of student undergraduate achievement and personality characteristics in a total web-based environment: An empirical study. Decision Sciences Journal of Innovative Education, 3(2), 205-221. https://doi.org/10.1111/j.1540-4609.2005.00067.x

Smith, T. J., Walker, D. A., Chen, H. T., Hong, Z. R., \& Lin, H. S. (2021). School belonging and math attitudes among high school students in advanced math. International Journal of Educational Development, 80, 102297. https://doi.org/10.1016/j.ijedudev.2020.102297

Stoet, G., \& Geary, D. C. (2018). The gender-equality paradox in science, technology, engineering, and mathematics education. Psychological science, 29(4), 581-593. https://doi.org/10.1177/0956797617741719

Sundre, D., Barry, C., Gynnild, V., \& Ostgard, E. T. (2012). Motivation for achievement and attitudes toward mathematics instruction in a required calculus course at the Norwegian University of Science and Technology. Numeracy, 5(1), 4. https://doi.org/10.5038/1936-4660.5.1.4

Tapia, M., \& Marsh II, G. E. (2004). An instrument to measure mathematics attitudes. Academic Exchange Quarterly, 8(2), 16-21.

Unfried, A., Faber, M., Stanhope, D. S., \& Wiebe, E. (2015). The development and validation of a measure of student attitudes toward science, technology, engineering, and math (S-STEM). Journal of Psychoeducational Assessment, 33(7), 622-639. https://doi.org/0.1177/0734282915571160

Utvær, H. T. (2019). Elevenes motivasjon for matematikk i barneskolen [Pupils' motivation for mathematics in primary school] (Bachelors thesis). NTNU, 2019 (In Norwegian).

Worthington, A., \& Higgs, H. (2004). Transmission of equity returns and volatility in Asian developed and emerging markets: a multivariate GARCH analysis. International Journal of Finance $\mathcal{E}$ Economics, 9(1), 71-80. https://doi.org/10.1002/ijfe.222

Yee, L. S. (2010). Mathematics Attitudes and Achievement of Junior College Students in Singapore [Paper Presentation]. Proceedings of the $33^{\text {rd }}$ Annual Meeting of the Mathematics Education Research Group of Australasia.

Yenilmez, K. (2007). Attitudes of Turkish high school students toward mathematics. International Journal of Educational Reform, 16(4), 318-335. https://doi.org/10.1177/105678790701600401 